\title{
Membaca Film Sebagai Sebuah Teks: Analisis Isi Film "Nanti Kita Cerita Tentang Hari Ini (NKCTHI)"
}

\author{
Rahman Asri \\ Program Studi Ilmu Komunikasi, Fakultas Ilmu Sosial dan Ilmu Politik, \\ Universitas Al Azhar Indonesia Komplek Masjid Agung Al Azhar Kebayoran Baru, \\ Jakarta Selatan 12110 \\ e-mail: rahman.asri@uai.ac.id
}

\begin{abstract}
Abstrak - Perkembangan dunia perfilman saat ini sudah berkembang pesat, tak terkecuali di Indonesia. Berbagai tema film telah diproduksi sebagai sarana hiburan maupun penyampaian pesan bagi khalayaknya. Penelitian ini bertujuan mendeksipsikan pesan (message) yang disampaikan dalam sebuah film dengan menganalisis isi (content analysis) secara kualitatif dalan paparan cerita film "Nanti Kita Cerita Tentang Hari INI (NKCTHI)" yang bergenre drama keluarga yang telah mendeskripsikan tentang kedudukan dan peran seorang lelaki, suami dan ayah dalam sebuah keluarga yang digugat oleh anak-anaknya sesuai perkembangan jaman mereka. Pesan cerita film NKCTHI ini menggugat dominasi laki-laki sebagai suami dan sekaligus ayah dalam latar belakang masyarakat yang masih patriarki, dimana otoritas dan pusat kekuasaan masih dominan pada laki-laki.
\end{abstract}

Kata Kunci-film, analisis isi, kualitatif, komunikasi massa, media

Abstract - Expanded growth in film industry all over the worlds, include Indonesia to released many theme and variant genre of movies for entertaintment and delivered messages for target audiences. The Objective of this study to describe about story message from family drama movie "Nanti Kita Cerita Tentang Hari Ini (NKCTHI)". This qualitative study used content analysis method with description about role and position a man as husband and father in traditional society with patriarchy, when a man handled authority and power dominantly, who sued by his lovely children in family.

Keywords - film, content analysis, qualitative, mass communication, media

\section{PENDAHULUAN}

耳ilm lm merupakan media komunikasi yang bersifat audio visual untuk menyampaikan suatu pesan kepada sekelompok orang yang berkumpul di suatu tempat tertentu. Film juga dianggap sebagai media komunikasi massa yang ampuh terhadap massa yang menjadi sasarannya, karena sifatnya yang audio visual, film mampu bercerita banyak dalam waktu yang singkat. Ketika menonton film, penonton seakan-akan dapat menembus ruang dan waktu yang dapat menceritakan kehidupan dan bahkan dapat mempengaruhi khalayak.[1]

Ada yang menganggap film merupakan sebuah tayangan hiburan semata, ada pula yang menganggap film adalah sebuah media yang dapat memberikan pembelajaran bagi penontonnya. Bagi pembuat film, tak jarang mereka membuat film atas dasar pengalaman pribadi atau pun kejadian nyata yang diangkat ke dalam layar lebar. Karena pada dasarnya Film selalu merekam realitas yang tumbuh dan berkembang di dalam suatu masyarakat dan kemudian memproyeksikanya ke dalam layar. [2]

Menurut Redi Panuju, film dapat menjadi media pembelajaran yang baik bagi penontonnya tidak semata menghibur, Film juga mampu menyampaikan pesan langsung lewat gambar, dialog, dan lakon sehingga menjadi medium yang paling efektif untuk menyebarkan misi, gagasan, dan kampanye, apapun itu. Hal itu disampaikannya dalam 
acara bedah buku "Film Sebagai Proses Kreatif' di Wisma Kalimetro (Kamis, 14 November 2019) dan juga menghadirkan Nuruddin sebagai pembahas, yang menekankan proses kreatif dalam film harus mendapatkan apresiasi dalam medium beragam juga. Nurudin menjelaskan, apresiasi yang beragam terhadap film dan industrinya agar menjadi faktor pendorong kemajuan film itu sendiri. Ilmu Komunikasi sudah serius melakukan beragam penelitian tentang film-film di Indonesia.[3]

Berbagai tema film telah diproduksi sebagai sarana hiburan maupun penyampaian pesan bagi khalayak yang menonton. Kekuatan format audio- visual dalam film dinilai mampu menyentuh perasaan dan moral khalayak. Film sering menjadi wadah bagi pembuatnya untuk menyampaikan pesan moral yang tersirat bagi penonton (audience target) dari film tersebut. Pesan-pesan tertentu dalam sebuah film dikomunikasikan untuk dibaca, atau di-decodekan oleh penonton, dan selanjutnya memengaruhi pemahaman individu penonton.[4]

Dapat dikatakan, film merupakan bagian dari komunikasi media massa bersifat audio-visual dan bertujuan untuk menyampaikan pesan sosial atau moral tertentu kepada penontonnya. Atasnya adanya realitas yang yang tumbuh dan berkembang di masyarakat, film pun dapat diciptakan hampir sama dengan apa yang penonton rasakan. Sehingga, saat menonton dan selesai menonton, penonton dapat merasakan sensasi kedekatan dengan adegan yang ada pada film tersebut. Tidak hanya adegan pada film, tapi maksud, tujuan, dan pesan pada film yang ditonton.

Komunikasi massa menghasilkan suatu produk berupa pesan-pesan komunikasi. Produk tersebut disebarkan, didistribusikan kepada khalayak luas secara terus menerus dan jarak waktu yang tetap, misal harian, mingguan, dwimingguan, atau bulanan. Proses produksi pesan tidak dapat dilakukan oleh perorangan, melainkan harus oleh lembaga, dan membutuhkan teknologi tertentu, sehingga komunikasi massa akan banyakan dilakukan oleh masyarakat industri film.[5]

Perkembangan dunia perfilman saat ini sudah berkembang pesat, tak terkecuali di Indonesia.
Menurut Ricky Josheph Pesik, Wakil Kepala Bekraf menyampaikan Indonesia dikenal sebagai pasar untuk film-film box office terbesar ke-16 di dunia dengan nilai pasar US\$ 345 juta atau sekitar Rp 4,8 triliun.[6] Berbagai macam film dari berbagai belahan dunia diproduksi dan tak jarang film-film tersebut ditayangkan juga pada bioskop di Indonesia.dengan beragam genre mulai dari horror sampai dengan action.

Menurut HB Naveen selaku Ketua Bidang Promosi dan Peredaran Asosiasi Perusahaan Film Indonesia (APFI) "Industri film sedang berada di puncak kejayaan, dengan box-office global mencapai rekor tertinggi pada 2019 sebesar 42,5 miliar dolar AS. Semua indikator tampak sangat baik dan jelas bahwa dunia kreatif -lah yang jadi pendorongnya."

Hal tersebut disampaikan di awal tahun 2020 saat menggelar acara diskusi film "Kaum Muda Indonesia dan Perilaku Menonton Film" pemaparan hasil survey yang dilakukan Saiful Mujani Research and Consulting (SMRC) yang diselenggarakan sebanyak 2 tahap September 2019 pada 103 Kabupaten/Kota dan di Desember 2019 (16 kota besar) dengan responden berusia 15 tahun lebih, semua kelompok ekonomi (SSE).[7] Berikut beberapa data hasil temuan lapangan pada penyelenggaraan survey tersebut.

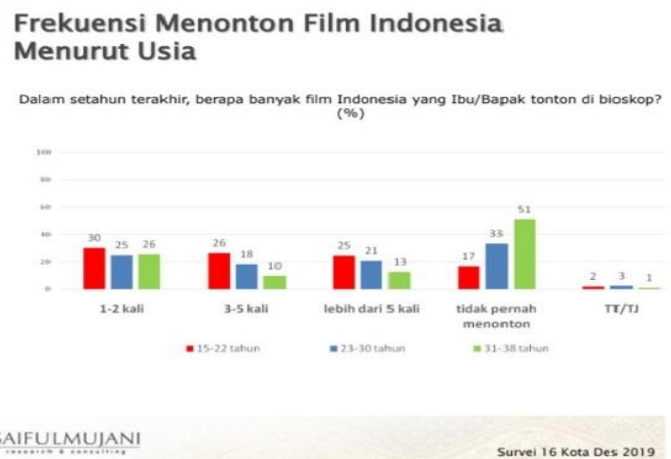

Gambar 1. Frekuensi menonton berdasarkan usia

Dari data survey SMRC terlihat penonton berusia 15-22 tahun (25\%-30\%), yang usia 2330 tahun (18\%-25\%), dan kelompok usia 31-38 tahun (10\%-26\%) dengan mengukur frekuensi menonton 1-2 kali, menonton 3-5 kali, dan lebih dari 5 kali ke bioskop. Sementara pilihan antara film Indonesia dan film Asing (produksi luar negeri) terlihat dalam tabel berikut ini: 
Tabel 1. Perbandingan Pilihan Film Yang Ditonton

\section{Menonton Film berdasarkan Kelompok Usia}

\begin{tabular}{|l|c|c|c|}
\hline & $\begin{array}{r}15-22 \\
\text { Tahun }\end{array}$ & $\begin{array}{c}23-30 \\
\text { Tahun }\end{array}$ & $\begin{array}{l}31-38 \\
\text { Tahun }\end{array}$ \\
\hline $\begin{array}{l}\text { Film } \\
\text { Indonesia }\end{array}$ & $81 \%$ & $64 \%$ & $49 \%$ \\
\hline Film Asing & $64 \%$ & $53 \%$ & $42 \%$ \\
\hline
\end{tabular}

SAIFULMUJANI

Survel 16 kota Des $2019 \quad 18$

Terlihat dari data pilihan untuk menonton Film Indonesia masih lebih besar dibandingkan pilihan terhadap film produksi luar negeri (Film Asing) dengan rentang persentase 49-81 persen pada ketiga kelompok usia dibandingkan yang memilih film Asing dengan angka 42-64 persen. Kesimpulan dari temuan ini menegaskan bahwa mayoritas kaum muda di kota-kota besar Indonesia menyatakan menonton film nasional di bioskop. Survei di 16 kota besar yang diselenggarakan (SMRC) pada Desember 2019 itu menunjukkan 67 persen kaum muda berusia 15-38 tahun menyatakan menonton setidaknya satu film nasional di bioskop dalam setahun terakhir. Sementara 40 persen menyatakan menonton setidaknya tiga film nasional selama setahun terakhir.[8]

Hasil survey SMRC dengan melibatkan 1.000 responden tersebut sekaligus menjawab keraguan bahwa minat kaum muda untuk kecenderungan menyukai film nasional ini semakin menguat di kalangan kelompok usia paling muda, 15-22 tahun. 81 persen dari kelompok usia tersebut menyatakan menonton setidaknya satu film nasional; sementara 51 persen menyaksikan setidaknya tiga film nasional di bioskop selama setahun terakhir. Genre film nasional yang paling disukai anak muda Indonesia adalah komedi (70,6 persen), diikuti dengan horor (66,2 persen), percintaan (45,6 persen) dan laga (37,4 persen). Sedangkan genre film asing yang disukai adalah laga (68 persen), diikuti dengan horor (65 persen), komedi (46,8 persen), percintaan ( 34,6 persen), misteri ( 21,8 persen).[9]

Menurut Chand Parwez Ketua Umum APFI, industry perfilman Indonesia memang menunjukkan pertumbuhan sejak 2016. Dia bersama APFI pun berkomitmen untuk menghadirkan karya-karya yang diminati penonton film di bioskop. "[Kami] berinvestasi dengan terus menghadirkan variasi genre dan kerja sama dengan berbagai pemangku kepentingan di bidang usaha, khususnya eksibitor, bidang kreatif, komunitas, dan pendidikan,"[10]

Satu diantara judul film rilis tahun 2020 dan menarik antusias penonton berjudul "Nanti Kita Cerita Tentang Hari Ini (NKCTHI)" yang disutradarai Angga Dwimas Sasongko, dengan bintang seperti Rio Dewanto, Sheila Dara Aisha, Rachel Amanda, Donny Damara, Susan Bachtiar, Oka Antara, Niken Anjani, dan Agla Artalidia yang masing-masing memerankan tokoh Angkasa (laki-laki, Si Sulung), Aurora (perempuan, anak tengah), dan Awan (perempuan, bungsu) beserta ayah-ibu mereka dalam beberapa periode usia. Beberapa bintang lainnya menjadi pelengkap karakter lain, Chicco Jerikho, Umay Shahab, Muhammad Adhiyat, Sinyo, Nayla Denny Purnama, Alleyra Fakhira Kurniawan, Syaqila Afiffah Putri serta musisi Ardhito Pramono.

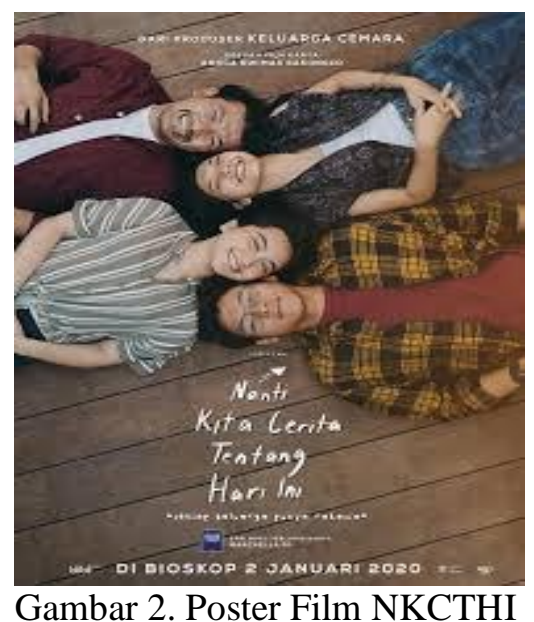

Kisah dalam film ini diangkat dari buku karya Marchella FP yang versi aslinya berisi pesanpesan pendek (quotes). Buku tersebut berisi kumpulan tulisan yang mencerminkan pengalaman pribadi seseorang yang sederhana, namun unik dan memikat. Pesan dalam buku itu diracik hingga menjadi sebuah cerita utuh mengenai kisah sebuah keluarga yang menyimpan sebuah rahasia. Format audio visual dari buku NKCTHI tersebut awalnya diadapatasi dalam sebuah format webseries sebanyak 3 episode pada sebuah channel youtube yang disponsori oleh perusahaan otomotif Indonesia. Berikut 3 episode tersebut: 
NKCTHI Eps.1

https://www.youtube.com/watch?v=G_nGsZntUzg NKCTHI Eps.2

https://www.youtube.com/watch?v=WdLlBMskryQ NKCTHI Eps.3

https://www.youtube.com/watch?v=1WRm5gqEX2 g

NKCTHI menjadi film ke-13 yang diproduksi Visinema Pictures dan tayang serentak di bioskop Indonesia pada 2 Januari 2020, sekaligus menandai 15 tahun kiprah Sutradara Angga Dwimas Sasongko di dunia penyutradaraan, dan satu dekade Rio Dewanto -pemeran Angkasa-- berkarya sebagai aktor. "Terima kasih penonton Indonesia, yang pasti saya sangat bahagia karena pesan dalam film ini bisa sampai ke sejuta hati," kata sutradara Angga Dwimas Sasongko, seperti dikutip dari rilis yang diterima Suara Pembaruan, edisi Jumat 10 Januari 2020. [11]

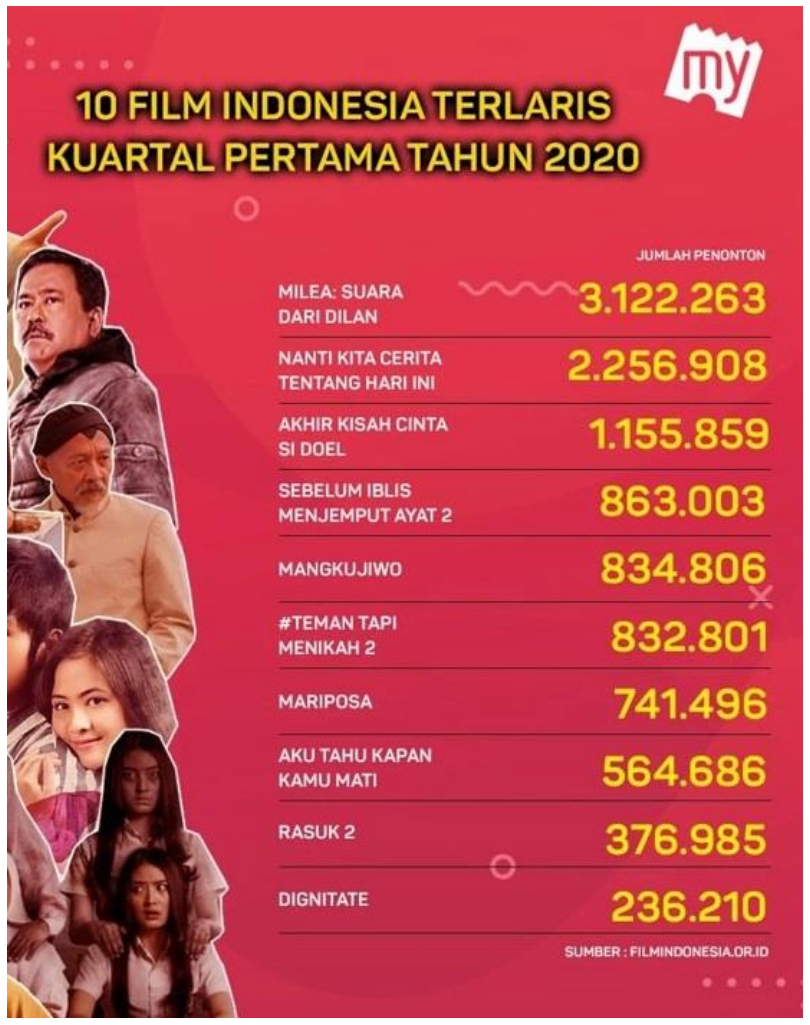

Gambar 3. Data Film Indonesia Terlaris

(kuartal pertama, Tahun 2020)

Rilis data penonton film NKCTHI berhasil meraih lebih dari 2 juta lebih penikmat karya tersebut, dan menduduki posisi no.2 di bawah film sekuel lanjutan film "dilan" yang berjudul "Milea: Suara Dari Dilan" yang meraih 3 juta lebih penonton selama periode kuartal I Tahun 2020. Film NKCTHI menjadi pembuka di awal tahun yang menembus angka 1 juta penonton.[12]

Dengan prestasi meraih penonton 2 juta lebih, antusiasme dan trending topic di jagat media sosial, serta menjadi bahasan banyak komunitas dan masyarakat secara umum terkait film tersebut, maka peneliti tertarik untuk mengangkat topik bahasan isi dari paparan cerita film NKCTHI khususnya untuk memperoleh jawaban apa sebenarnya isi atau pesan yang disampaikan dalam penceritaan di film NKCTHI tersebut.

Maka dengan latar belakang permasalahan tersebut, peneliti akan menggunakan pendekatan analisis isi (content analysis) kualitatif dalam melakukan kajian terhadap isi atau pesan yang ada dalam cerita film "Nanti Kita Cerita Tentang Hari Ini (NKCTHI)." Tujuan dari penelitian ini diharapkan akan memberikan deskripsi dari isi atau pesan dalam cerita film NKCTHI sehingga khalayak bisa lebih memahami inti pesan dari penceritaan dalam sebuah film.

\section{TINJAUAN PUSTAKA}

\section{Perkembangan Komunikasi Media Massa}

Saat ini seiring perjalanan peradaban manusia melalui penemuan teknologi termasuk di dalamnya teknologi komunikasi, bisa dikatakan hampir seluruh masyarakat sudah menggunakan atau mengkonsumsi media massa dalam format beragam dan tingkat kecanggihan teknologi yang berbeda.

Media massa sendiri adalah alat yang digunakan dalam penyampaian pesan dari sumber kepada khalayak dengan menggunakan alat-alat komunikasi seperti surat kabar, film, radio dan televise [13]. Dalam buku Crisis Public Relations, Firsan Nova (2009) mengutip McLuhan yang mengemukakan, bahwa media massa merupakan perpanjangan alat indera kita. Melalui media massa kita memperoleh informasi tentang benda, orang, atau tempat yang tidak kita alami secara langsung [14]

Pengertian lain komunikasi massa adalah proses penyampaian informasi, ide, dan sikap kepada banyak orang (biasanya dengan menggunakan mesin atau media yang diklasifikasikan ke dalam media massa, seperti 
radio, televisi, surat kabar/majalah dan film) [15] Komunikasi massa harus dilakukan dengan menggunakan media massa dimana yang termasuk media massa adalah radio dan televisi (media elektronik), surat kabar dan majalah (media cetak) serta media film. Film sebagai media komunikasi massa adalah film bioskop [16].

Berikut ini beberapa karakter yang dimiliki komunikasi massa : (1) bersifat satu arah, (2) komunikasi massa melembaga, (3) melahirkan Keserempakan, serentak, (4) komunikan yang menjadi target sifatnya heterogen.[17]

Media komunikasi massa merupakan saluran komunikasi yang digunakan untuk menghasilkan dan mendistribusikan berita, konten hiburan, visual, dan produk budaya lainnya ke sejumlah besar orang. Oleh karena itu media komunikasi berkaitan dengan sejumlah orang atau massa, maka disebut media komunikasi massa atau lebih disingkat dengan media massa[18].

Fungsi media massa secara umum adalah sebagai berikut: 1. Media massa memiliki fungsi sebagai pengantar (pembawa) bagi segenap macam pengetahuan. 2. Media massa menyelenggarakan kegiatan dalam lingkungan publik. 3.Pada dasarnya hubungan antar pengirim dan penerima pesan seimbang dan sama.

Komunikasi massa dapat di definisikan sebagai proses komunikasi yang berlangsung dimana pesannya dikirim dari sumber yang melembaga kepada khalayak melalui alat-alat yang bersifat mekanis. Pada dasarnya komunikasi massa adalah komunikasi yang menggunakan media massa, baik media cetak maupun media elektronik. Sebab awal perkembangannya, komunikasi massa berasal dari pengembangan kata 'media of mass communication.' [19]

Media massa bekerja menyampaikan informasi, untuk khalayak. Dari informasi itu kita dapat membentuk, mempertahankan, atau mendefinisikan citra.

\section{Membaca Film Sebagai Sebuah Teks}

Film di artikan sebagai lakon, artinya film tersebut mempresentasikan sebuah cerita dari tokoh tertentu secara utuh dan berstruktur. Istilah ini yang lebih sering dikaitkan dengan drama, yakni sebuah seni peran yang divisualkan.

Pengertian lebih lengkap dan mendalam tercantum jelas dalam pasal 1 ayat (1) UU Nomor 8 Tahun 1992 tentang Perfilman, dimana disebutkan bahwa yang dimaksud dengan film adalah karya cipta, seni dan budaya yang merupakan media komunikasi massa pandang dengar yang dibuat berdasarkan asas sinematografi dengan direkam pada pita seluloid, pita video, piringan video, dan/atau lainnya.[20]

Sedangkan menurut pasal 1 ayat (1) Undang Undang Republika Nomor 33 Tahun 2009 Tentang Perfilman, "Film adalah karya seni budaya yang merupakan pranata sosial dan dapat dipertunjukan". Tetapi secara umum film adalah media komunikasi yang mampu mempengaruhi cara pandang individu yang kemudian akan membentuk karakter suatu bangsa.[21]

Dalam konteks komunikasi massa, sebuah film dimaknai sebagai pesan yang disampaikan dalam komunikasi filmis yang memahami hakikat, fungsi, dan efeknya. Sedangkan dalam praktik sosial, film dilihat tidak sekedar ekspresi seni pembuatannya, tetapi interaksi antar elemen-elemen pendukung, proses produksi, distribusi maupun ekspidisinya. Bahkan lebih jauh dari itu, Perspektif ini mengasumsikan interaksi antar film dengan ideologi serta kebudayaan dimana film di produksi dan di konsumsi[22]

Menurut Baskin (2003), film merupakan salah satu bentuk media komunikasi massa dari berbagai macam teknologi dan berbagai unsurunsur kesenian. Film jelas berbeda dengan seni sastra, seni lukis, atau seni memahat. Seni film sangat mengandalkan teknologi sebagai bahan baku untuk memproduksi maupun eksibisi ke hadapan penontonnya[23].

Dari pengertian ini bisa disimpulkan bahwa film merupakan salah satu media atau perantara yang dipakai untuk menyampaikan pesan komunikasi kepada sekelompok orang yang bersifat besar yaitu komunikasi massa. Pesan yang disampaikan pun bermacam-macam, tergantung dengan apa yang ingin disampaikan oleh para pembuat film itu sendiri. Pesan yang sampai dan diterima oleh audience atau 
khalayak pun akan berbeda antara satu individu dan individu lainnya.[24]

Film merupakan media yang dapat menjadi cermin realitas sosial di masyarakat, sekaligus juga sebagai agen konstruksi realitas. Film sebagai cermin realitas merupakan gambaran bahwa melalui film diberikan gambaran ide ide, makna dan pesan yang terkandung dalam cerita sebuah film yang merupakan interaksi dan pergulatan wacana antara sineas pembuat film dan masyarakat serta realitas yang ditemui para sineas tersebut. Sedangkan film sebagai sarana konstruksi realitas adalah ketika para sineas telah membangun suatu objektivasi tentang sebuah ide dan pemikiran, lalu hal itu dikonstruksikan ulang dalam bentuk symbol dan teks dalam film berupa adegan, dialog, setting, dan lain sebagainya. Maka fim menjadi produk budaya yang kemudian berinteraksi dengan masyarakat dalam suatu eksternalisasi sebagai awal dari siklus konstruksi realitas sosial. [25]

Dalam film antara realitas sosial dan konstruksi realitas dipadukan, yang menjadikan sebuah film dapat menjadi sarana untuk memahami fenomena yang terjadi dalam masyarakat. Film sering menjadi tolak ukur keadaan masyarakat yang sebenarnya, sebagai refleksi realitas sosial yang ada.[26]

Menurut Peter L. Berger dan Thomas Luckman dalam The Social Construction of Reality A Treatise in the Sociology of Knowledge (1966), konstruksi digambarkan sebagai proses sosial melalui tindakan dan interaksi, dimana individu menciptakan secara terus menerus suatu realitas yang dimiliki dan dialami bersama secara subjektif. Realitas tidaklah terbentuk secara alami tetapi dibentuk dan dikonstruksikan melalui proses eksternalisasi (penyesuaian diri dengan dunia sosiokultural sebagai produk manusia), objektivasi (interaksi sosial yang terjadi dalam dunia intersubjektif yang dilembagakan) dan internalisasi (proses dimana individu mengidentifikasikan dirinya ke dalam lembaga sosial dimana dirinya berada). [27]

Namun Burhan Bungin berpandangan, posisi konstruksi realitas sosial dilengkapi dengan konstruksi realitas media dengan menempatkan seluruh kelebihan media massa. Realitas media merupakan bagian dari rekonstruksi sosial masyarakatnya. Karena itu, ketergantungan mereka yang hidup dalam realitas media adalah orangorang yang selalu memiliki kesadaran realitas ini, sebagaimana ia menyadari dirinya sebagai bagian dari realitas itu sendiri.[28]

Sejarah film dimulai pada 28 Desember 1895, pemutaran film komersial pertama di dunia berlangsung di Grand Cafe di Paris. Film ini dibuat oleh Louis dan Auguste Lumiere, keduanya berasal dari Perancis yang mengembangkan proyektor kamera Cinematographe. Lumiere. Penemuan dua bersaudara itu diawali dengan peluncuran penemuan mereka kepada publik pada Maret 1895 dengan sebuah film pendek yang memperlihatkan para pekerja meninggalkan pabrik Lumiere. [29]

Film adalah media yang bersifat visual dan audio untuk menyampaikan pesan kepada sekelompok orang yang berkumpul di suatu tempat. [30] Menurut pengertian lain, film adalah media audio-visual yang menggabungkan kedua unsur, yaitu naratif dan sinematik. Unsur naratif sendiri berhubungan dengan tema, sedangkan unsur sinematik jalan alur atau jalan ceritanya. [31]

Definisi lain terkait film adalah karya seni budaya yang merupakan pranata sosial dan media komunikasi masa yang dibuat berdasarkan kaidah sinematografi dengan atau tanpa suara yang dipertunjukan. Pranata yang dimaksud adalah tataan atau menata, dalam arti singkat film mempunyai peran untuk menata kehidupan para penontonnya baik secara positif maupun negatif dimana film-film tersebut mempunyai suatu pesan yang disisipkan untuk penonton. [32]

\section{Film Sebagai Alat Propaganda}

Dalam sejarah perkembangan film terdapat dua tema besar yang menjadi tonggak sejarah penting: Tema pertama, adalah pemanfaatan film sebagai alat propaganda, tema ini penting terutama dalam kaitannya dengan upaya pencapaian tujuan aslinya dan masyarakat. Hal tersebut berkenaan dengan pandangan yang menilai bahwa film memiliki jangkauan, realism, pengaruh emosional, dan popularitas yang hebat. Tema Kedua, dalam sejarah film munculnya beberapa aliran seni film dan lahirnya aliran film dokumentasi sosial. Kedua kecenderungan tersebut merupakan suatu 
penyimpangan dalam pengertian bahwa keduanya hanya menjangkau minoritas penduduk dan berorientasi realism. Terlepas dalam hal itu, keduanya mempunyai kaitan dengan tema" film sebagai alat propaganda." [33]

Dalam sejarah perang dunia, film juga telah menjadi sarana efektif untuk menjadi mesin propaganda pihak tertentu untuk menguatkan misi maupun psywar umtuk menjatuhkan mental musuh atau lawannya. Berikut lima film propaganda dikutip dari okezone.com: [34]

1. Ivan The Terrible- Part I (1944), proses film ini diberikan ijin produksi oleh Diktator Soviet, Joseph Stalin untuk membangkitkan semangat rakyat Uni Sovyet sedang terlibat perang melawan Jerman di perang dunia, WW II.

2. Casablanca (1942), film ini dibuat sebelum Amerika terlibat dalam perang dunia WW II, dan dinilai sukses membangun simpati rakyat Amerika untuk menentang Nazi Jerman. Dan ketika pihak Amerika turut perang, rakyat sudah memahami mereka berada di pihak mana, pihak Sekutu menghadapi Nazi Jerman.

3. The Birth of a Nation (1915), film berlatar sejarah perang saudara Amerika dianggap telah memberikan stereotype terhadap orang kulit hitam dan dikritik keras karena rasis.

4. Battleship Potemkin (1925), film yang memberikan penggambaran tentara Rusia yang membantai rakyat sipil yang fakta sebenarnya tidak pernah terjadi. Film propaganda Partai Komunis Rusia itu berhasil mendramatisasi untuk menggambarkan pemerintah Rusia di bawah kekuasaan Tsar yg jahat.

5. Triumph of The Will (1935), film propaganda Nazi ini dinilai sebagai film propaganda terbaik dan juga membuat banyak revolusi teknis perfilman melalui cinematography seperti shooting dari udara, pergerakan dan komposisi kamera yang dinamis, penggunaan lensa fokus panjang dan peggunaan musik berbeda. film ini mendapatkan penghargaan di Venice Biennale dan Grand Prix exhibition di Paris.

Ada beberapa film heroik berlatar perang dinilai juga berisi propaganda Amerika: Pearl
Harbor (2001) ikhtiar pencitraan militer Amerika Serikat, The Sum Of All Fears (2001), Amerika Serikat berusaha menaikkan citra dirinya sebagai bangsa, Iron Man (2008), pameran kekuatan udara Amerika Serikat, Argo (2012), kampanye mencitrakan Iran sebagai negara buruk, The Interview (2014), potret kebencian Amerika Serikat terhadap Korea Utara.[35]

Bahkan menurut Listverse.com (6/2/2017) yang dikutip oleh liputan6.com pada masa perang dunia, WW II perusahaan film Walt Disney mendapat tugas pemerintah AS dan Kanada untuk membuat propaganda perang terkait bond pendanaan perang dan pembayaran pajak. Digambarkan dalam sebuah adegan, sosoksosok Disney berbaris bersama dari berbagai film-film seperti Snow White, Pinocchio, Mickey, Gooffy dan kawan-kawan berjalan beriringan dalam sebuah defile pawai. [36]

Di Indonesia, film propaganda yang begitu dirasakan pada film "Pengkhianatan G30S/PKI", "Operasi Trisula", "Janur Kuning" dan masih banyak lagi yang biasanya dibuat oeh Pusat Perfilman Nasional (PPFN) sebagai lembaga penerangan pemerintah. Dari berbagai film dengan berbagai latar belakang dan tema cerita, pasti semuanya memuat 'pesan' tertentu dalam filmnya. Sifat pesan yang ingin disampaikan tidak selalu berupa propaganda, melainkan juga gagasan, ide, atau sudut pandang pemikiran, perspektif yang berbeda atau baru dalam melihat permasalahan yang berkembang di masyarakat.

Terkait pengaruh efek media massa kepada khalayak atau audiens yang menjadi target sasarannya, McQuail (2005) yang menjadi premis seluruh penelitian tentang komunikasi massa adalah adanya pengaruh dan efek yang ditimbulkan oleh media massa kepada khalayak atau audiens yang menjadi target sasarannya. Film termasuk ke dalam media massa, adapun terdapat pesan yang disampaikan dalam film, dan juga efek yang ditimbulkan setelah menonton film. Efek yang ditimbulkan dibagi menjadi efek kognitif, efek afektif, dan efek behavioral. [37]

1. Efek Kognitif, terjadi bila ada perubahan pada apa yang diketahui, dipahami, atau dipersepsi khalayak. 
2. Efek Afektif, muncul bila ada perubahan pada apa yang, dirasakan, disenangi, atau dibenci khalayak.

3. Efek Behavioral, merujuk pada perilaku nyata yang dapat diamati; yang meliputi pola - pola tindakan, kegiatan, atau kebiasaan berperilaku. [33]

\section{METODE PENELITIAN}

Metode analisis isi (content analysis) merupakan teknik penelitian untuk membuat replikan dan terjemahan valid dari teks kepada konteks yang perlu diteliti. Sebagai sebuah teknik, analisis isi memerlukan beberapa prosedur, analisis isi bisa dipelajari dan tidak digunakan tergantung otoritas peneliti. Metode analisis isi (content analysis) menyediakan pandangan baru, dan meningkatkan pemahaman peneliti untuk fenomena tertentu atau menginformasikan sebuah aktivitas praktikal. [38]

Dalam kajian ilmu komunikasi, metode analisis isi (content analysis) digunakan sebagai metode untuk meneliti komponen sebuah pesan komunikasi (message). Dalam rumpun ilmuilmu lain seperti teologi, bahasa, sastra-seni, dan sejarah, metode analisis isi sering dijadikan metode dalam penelaahan teks kitab suci, karya sastra dan seni, foto, gambar, lukisan, buku, syair lagu, dan catatan-catatan tertulis (manuscript). Analisis isi dapat dilakukan secara kualitatif maupun kuantitatif. [39]

Metode analisis isi (content analysis) berfokus pada karakteristik bahasa sebagai komunikasi dengan perhatian pada isi atau arti kontekstual teks. Analisis isi kualitatif diartikan sebagai metode riset untuk interpretasi subjektif dari isi data melalui proses klasifikasi sistematis koding dan indentifikasi tema atau pola. Ada 3 pendekatan dalam metode analisis isi kualitatif: konvensional, terarah dan penggabungan. [40]
Tabel.2. Perbedaan Koding Utama diantara 3 Pendekatan dalam Analisis Isi Kualitatif

\begin{tabular}{|c|c|c|c|}
\hline $\begin{array}{l}\text { Type Of } \\
\text { Content } \\
\text { Analysis }\end{array}$ & $\begin{array}{l}\text { Study } \\
\text { Start } \\
\text { With }\end{array}$ & $\begin{array}{l}\text { Timing } \\
\text { of } \\
\text { Defining } \\
\text { Codes or } \\
\text { Keyword }\end{array}$ & $\begin{array}{l}\text { Sources of } \\
\text { Codes \& } \\
\text { Keywords }\end{array}$ \\
\hline $\begin{array}{c}\text { Conventional } \\
\text { Content } \\
\text { Analysis }\end{array}$ & Observation & $\begin{array}{l}\text { Code are } \\
\text { defined } \\
\text { during } \\
\text { data } \\
\text { analysis }\end{array}$ & $\begin{array}{l}\text { Codes are } \\
\text { derived } \\
\text { from data }\end{array}$ \\
\hline $\begin{array}{l}\text { Directed } \\
\text { content } \\
\text { Analysis }\end{array}$ & Theory & $\begin{array}{l}\text { Codes are } \\
\text { defined } \\
\text { before and } \\
\text { during } \\
\text { data } \\
\text { analysis }\end{array}$ & $\begin{array}{c}\text { Codes are } \\
\text { derived } \\
\text { from } \\
\text { theory/relevant } \\
\text { research findings }\end{array}$ \\
\hline $\begin{array}{c}\text { Summative } \\
\text { content } \\
\text { Analysis }\end{array}$ & Keywords & $\begin{array}{l}\text { Keywords } \\
\text { are } \\
\text { identified } \\
\text { before and } \\
\text { during } \\
\text { data } \\
\text { analysis }\end{array}$ & $\begin{array}{l}\text { Keywords are } \\
\text { derived from } \\
\text { interest of } \\
\text { researcher/review } \\
\text { of literature }\end{array}$ \\
\hline
\end{tabular}

Sumber: Hsieh \& Shannon (2005)

Penelitian atau studi ini akan menggunakan pendekatan conventional content analysis yang berawal dari pengamatan (observation).

\section{HASIL DAN PEMBAHASAN}

Film sebagai medium (media massa) penyampai pesan pada dasarnya adalah sebuah teks yang memiliki makna. Sebagai 'teks' yang menyampaikan sebuah pesan, maka kegiatan menonton film tak berbeda seperti layaknya membaca buku.

Dalam proses "pembacaan" sebuah film, segenap khazanah memori kita terlibat dan akan menjadi landasan, dasar bagaimana kita mengupas makna film tersebut. Khazanah dalam benak kita itu meliputi berbagai bahan bacaan lain dari berbagai sumber akan menjadi wawasan, pengalaman apapun yang dimana kita menyerapnya baik pengalaman baik maupun traumatis. Dan juga sistem nilai masyarakat yang sudah terbentuk dalam diri kita akan turut menjadi sandaran 
Saat kita membaca teks dalam sebuah film. Bisa jadi, pembaca teks terhadap sebuah film adalah pengalaman subyektif sesuai dengan wawasan, pengalaman dan tata nilai masyarakat yang dianut seseorang.

Medium film sebagai format media massa selain memfungsikan dirinya sebagai sarana hiburan, film juga dapat menjadi media pembelajaran sekaligus proses 'sosialisasi' dimana nilai-nilai disampaikan kemudian diserap oleh khalayak dan akan terjadi proses internalisasi yang kemudian menjadi sikap seseorang.

Melalui film akan disampaikan pesan tertentu (message) melalui gambar, dialog, setting gambar, penokohan, plot alur cerita, simbolsimbol, musik dan apa yang disajikan di layar lebar. Film mampu secara efektif digunakan sebagai media untuk menyebarkan misi, gagasan, dan kampanye apapun pesan yang akan disebarkan atau disampaikan seseorang, lembaga atau pemerintah.

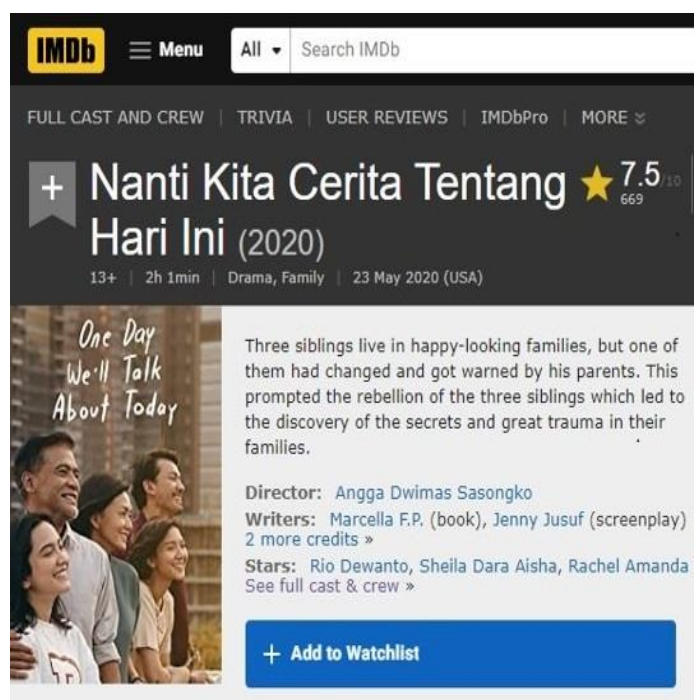

Gambar 4. Film NKCTHI (IMDb.com)

Tittle : Nanti Kita Cerita Tentang Hari Ini (NKCTHI)

PG 13+ | length 2h 1min | genre: Drama, Family |

Director: Angga Dwimas Sasongko

Writing Credits (in alphabetical order):

Marcella F.P. $\quad$... (book)

Jenny Jusuf $\quad \ldots \quad$ (screenplay)

Mohammad Irfan Ramly (screenplay)

Melarissa Sjarief ... (screenplay)

Writers: Jenny Jusuf (script writer), Mohammad Irfan Ramly (screenplay)

Stars: Rio Dewanto, Sheila Dara Aisha, Rachel

Amanda, Donny Damara, Susan Bachtiar, Oka
Antara, Niken Anjani, Agla Artalidia Chicco Jerikho, Umay Shahab, Muhammad Adhiyat, Sinyo, Nayla Denny Purnama, Alleyra Fakhira Kurniawan, Syaqila Afiffah Putri, Ardhito Pramono.[41]

Film "Nanti Kita Cerita Tentang Hari Ini (NKCTHI)" merupakan karya sutradara Angga Dwimas Sasongko satu diantara film drama keluarga yang memberikan penyajian cerita dalam film yang jika kita membaca 'teks' nya akan diperoleh 'pesan' (messages) yang cukup bermakna.

Film NKCTHI mengisahkan tentang sebuah keluarga yang menyimpan sebuah 'rahasia'. Si Sulung laki-laki, Angkasa (Rio Dewanto), perempuan Si Anak Tengah, Aurora (Sheila Dara) dan perempuan Si Bungsu, Awan (Rachel Amanda), kakak beradik yang hidup dalam keluarga tampak bahagia. Namun, setelah mengalami kegagalan besar pertama di tempat kerjanya, Si Bungsu Awan berkenalan dengan Kale, laki-laki pemusik eksentrik yang memberinya pengalaman hidup baru mengenai patah, bangun, jatuh, tumbuh dan ketakutan manusia pada umumnya. Awan, Si Bungsu yang mulai mencicipi dinamika hidup, jatuh dan bangun serta pahitnya gagal sebagai bagian dari proses pendewasaan. [42]

Setelah berkenalan dengan Kale, si pemusik dengan sikap eksentriknya, sifat Awan perlahan mulai berubah. Perubahan sikap Awan mendapat tekanan dari orang tuanya. Imbas dari kejadian tersebut, tiga kakak beradik itu pun mulai memberontak hingga akhirnya rahasia keluarga mereka terungkap yang merupakan sebuah trauma 'luka' besar dalam keluarga mereka. Dari sisi penceritaan film NKCTHI memiliki alur multiplot dimana penceritaan dalam film tersebut, selain memiliki cerita utama (dalam film NKCTHI, kisah keluarga terkait kisah orang tua dan ketiga anak mereka), juga memiliki plot-plot terpisah pada masing-masing anak: Angkasa, Aurora, dan Awan, dimana ketiganya memiliki cerita sedih-pilunya sendiri dengan permasalahan yang berbeda. 


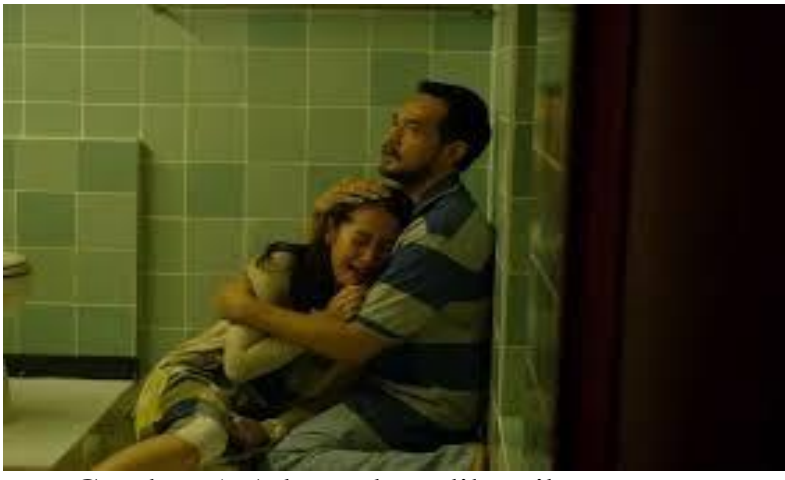

Gambar 5. Adegan kesedihan ibu yang kehilangan seorang bayi kembar yang meninggal

Dalam kisah film NKCTHI yang dimaksud trauma 'luka' besar dalam keluarga itu adalah kehilangan salah satu anak kembar mereka (kembaran Si Bungsu, Awan) yang meninggal sesaat kelahiran. Berharap bisa menghapus musibah keluarga itu, Sang Ayah melarang isterinya dan anak-anak agar tidak larut dalam kesedihan. Berusaha mengubur kisah sedih itu dalam-dalam, setiap anggota tidak dibolehkan Sang Ayah bersikap murung. Namun di kemudian hari, sikap yang mengabaikan rasa sedih, kecewa, merasa gagal ini menyisakan permasalahan dalam menyikapi persoalan kehidupan mereka sehari-hari.

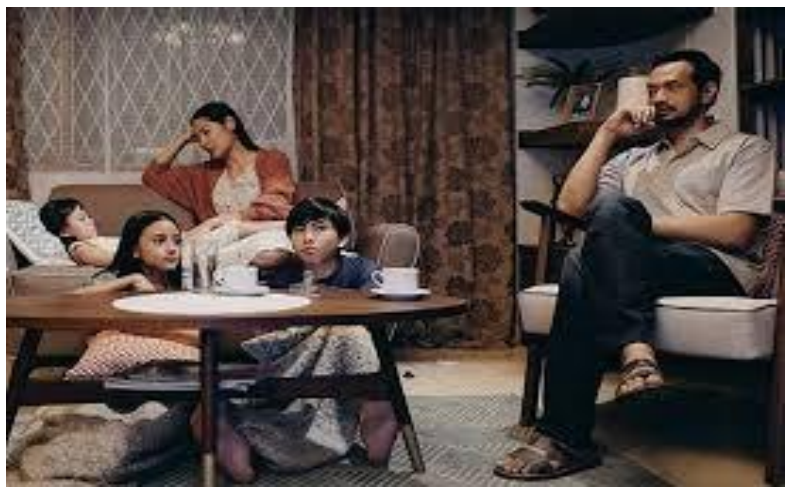

Gambar 6. Adegan di ruang keluarga dimana peran Ayah tergambar dominan dan pemegang otoritas

Sikap tegas yang ditetapkan Sang Ayah bagi semua anggota keluarga dalam menanggapi musibah keluarga tersebut, serta mendominasi dalam berbagai kejadian maka Sang Ayah dideskripsikan menjadi "King of The Rule" untuk bisa menentukan boleh atau tidaknya apa yang dilakukan pada setiap anggota dalam keluarga. Sentral keluarga itu adalah Sang Ayah, isteri dan anak-anak hanya diminta patuh atas keputusan yang telah ditetapkan.

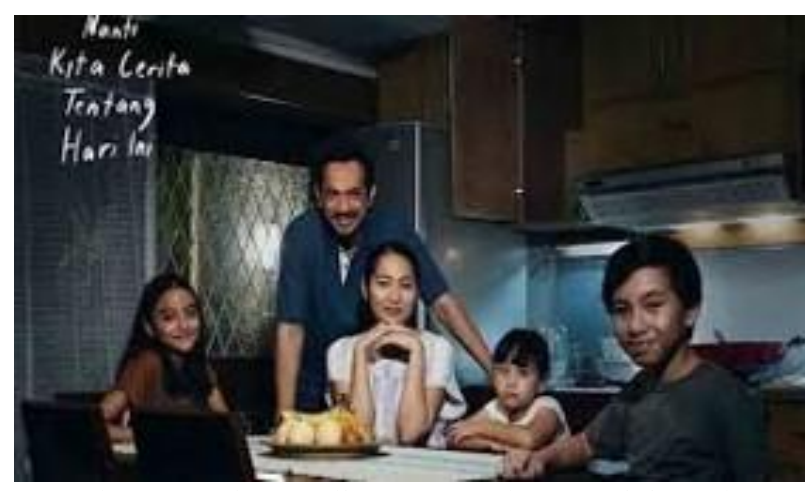

Gambar 7. Adegan di ruang makan posisi ayah sebagai tulang punggung sekaligus menentukan

Penggambaran sosok utama Sang Ayah yang digambarkan dalam film seperti mewakili pandangan masyarakat selama ini dalam sistem patriarki, dimana peran laki-laki menjadi dominan dan menentukan dalam keluarga tradisional. Otoritas Sang Ayah sebagai kepala keluarga begitu besar, tak terimbangi oleh isteri terlebih anak-anak. Namun seiring modernisasi dan perkembangan yang berkembang di masyarakat, kondisi demikian tidak lagi sepenuhnya bisa diterima.

Peran wanita, dalam hal ini seorang isteri sekaligus ibu baik yang bekerja maupun tidak bekerja tidak lagi terkukung dengan pekerjaan domestik di dalam rumah. Perkembangan teknologi komunikasi dan interaksi sosial yang bisa terjalin meskipun berjarak sangat memungkinkan wanita (isteri dan sekaligus sebagai ibu rumah tangga) melakukan pengembangan dirinya dalam banyak aspek kehidupan bahkan mampu menjalankan bisnis sampingan untuk menunjang ekonomi keluarga. Terlebih bagi seorang ibu bekerja yang bisa meraih tangga karir di tempat kerjanya sejauh yang dimungkinkan dengan prestasi yang bisa mendorongnya maju.

Plot-plot lain dari berbagai cerita perjuangan suka-duka dari anak-anak (Angkasa, Aurora, Awan) menjadikan film NKCTHI memiliki cerita multiplot yang membuat film mejadi lebih berwarna. Kekecewaan karena sebuah mimpi yang terkubur, tarik-menarik kepentingan antara prioritas urusan pribadi, pekerjaan dan keluarga. Meskipun ketiga kakak-beradik Angkasa, Aurora, dan Awan saling mendukung dan saling melindungi, namun mereka menyadari bahwa kehidupan sosial manusia sesungguhnya secara realitas lebih luas dari itu (bukan hanya antar anggota 
keluarga). Kehidupan sosial banyak terkait dalam interaksi dengan orang-orang lain di luar keluarga, apakah seorang teman, sejawat, teman dekat atau kekasih dan orang-orang lain yang ada di sekitar mereka.

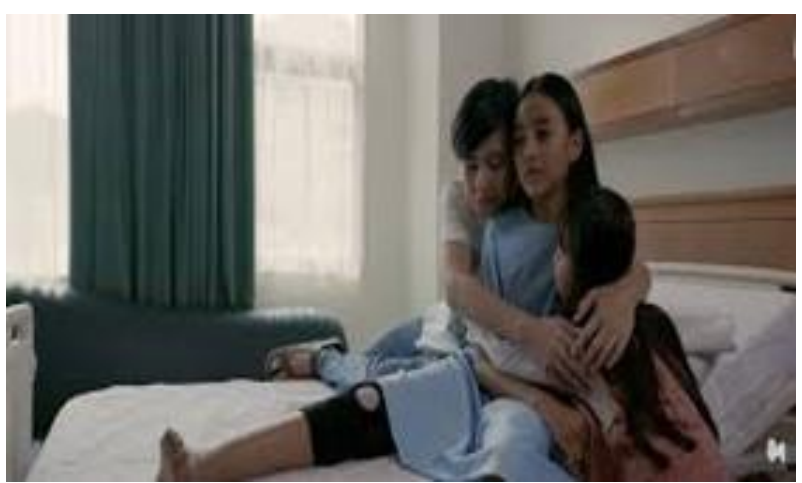

Gambar 8. Adegan kesedihan Aurora (Si Anak

Tengah) karena cedera kaki pupus mimpinya untuk berprestasi di olahraga renang yang ditekuninya.

Film NKCTHI bergenre drama keluarga seperti menyampaikan sebuah 'pesan' (message) bahwa kehidupan akan selalu berubah. Mengubah sebuah peran dan fungsi sebuah posisi, meskipun di dalam lingkup keluarga. Dengan perubahan yang berjalan akan menjadikan posisi seorang berubah, meninjau ulang hubungan (interaksi dan relasi) yang sudah ada dan memperbaikinya agar lebih terkoneksi dengan dinamika yang terjadi saat ini.

'Pesan' (message) baik yang tersurat karena tergambarkan dalam cerita, adegan film dari akting para pemerannya maupun yang tersirat dalam ungkapan dialog, penggambaran suasana (setting) tentunya akan ditangkap secara subyektif pada masing-masing orang sesuai dengan latar belakang, pengalaman dan pengetahuannya.

\section{KESIMPULAN}

Dari kajian analisis isi (content analysis) yang dilakukan pada film nasional "Nanti Kita Cerita Tentang Hari Ini (NKCTHI)" dapat disimpulkan film sebagai sebuah medium dapat digunakan untuk menyampaikan sebuah pesan tentang peran seorang laki-laki (sebagai suami, sekaligus seorang ayah) dalam sebuah keluarga. Proses pembacaan 'teks' dalam sebuah film dimana segenap khazanah memori kita terlibat dan akan menjadi landasan, meliputi berbagai bahan bacaan lain dari berbagai sumber akan menjadi wawasan, pengalaman dan juga sistem nilai masyarakat yang sudah terbentuk dalam diri kita akan turut menjadi sandaran penilain terhadap sebuah film.

Pembacaan 'teks' dalam cerita film NKCTHI cukup tergambarkan dominannya peran Sang Ayah (laki-laki) sebagai seorang suami sekaligus ayah anak-anaknya begitu dominan dan memegang otoritas penuh dalam keluarga seperti pemahaman patriarki dalam masyarakat tradisional dimana seorang laki-laki "King of The Rule" yang menentukan sikap boleh atau tidaknya bagi setiap anggota keluarga dalam menghadapi permasalahan.

Namun sesuai perkembangan baik secara teknologi dan peradaban manusia saat ini pandangan patriarki (menurut KBBI, sebagai perilaku mengutamakan laki-laki daripada perempuan dalam masyarakat atau kelompok sosial tertentu) digugat dan dipertanyakan seiring perubahan yang berjalan dan meninjau ulang hubungan (interaksi dan relasi) yang sudah ada dan memperbaikinya agar lebih terkoneksi dengan dinamika yang terjadi saat ini.

\section{DAFTAR ACUAN/PUSTAKA}

[1] Stanley J. Baran. 2012. Pengantar Komunikasi Massa Literasi Media dan Budaya (terjemahan) Jakarta: Salemba Humanika, Hal. 231.

[2] Alex Sobur. 2006. Semiotika Komunikasi. Bandung:Remaja Rosdakarya. Hal 126- 127.

[3] intranspublishing.com. "Bedah Buku Film Sebagai Proses Kreatif" http://intranspublishing.com/bedahbuku-film-sebagai-proses-kreatif/, diakses pada 23 Agustus 2020 jam 15:16.

[4] M. Ilham Zoebazary. 2010. Kamus Istilah Televisi dan Film. Jakarta : PT Gramedia Pustaka Utama. Hal. 159.

[5] Khomsahrial Romli. 2016. Komunikasi Massa. Jakarta: Kompas Gramedia. Hal. 2.

[6] Heri Susanto. 2019." Tumbuh Pesat Indonesia Pasar Potensial bagi Industri 
Film"https://katadata.co.id/berita/2019/0 3/16/tumbuh-pesat-indonesia-pasarpotensial-bagi-industri-film di akses pada 22 Agustus 2020 jam 13:11

[7] saifulmujani.com. "67 Persen Anak Muda Indonesia Menonton Film Nasional dan Hanya 55 Persen Menonton Film Asing" https://saifulmujani.com/67-persen-anakmuda-indonesia-menonton-filmnasional-dan-hanya-55-persenmenonton-film-asing/ diakses pada 22 Agustus 2020 jam 13:31.

[8] ibid.

[9] inews.id "Film Nasional Ternyata Banyak Ditonton GenerasiMilenial"https://www.inews.id/1 ifestyle/film/film-nasional-ternyatabanyak-ditonton-generasi-milenial diakses pada 22 Agustus 2020 jam 14:30

[10] bisnis.com."Generasi Muda Masih Suka Tonton Film Nasional" https://lifestyle.bisnis.com/read/2020011 6/220/1191082/generasi-muda-masihsuka-tonton-film-nasional diakses pada 23 Agustus 2020 jam 16:35.

[11] beritasatu.com. "Film NKCTHI Torehkan Sejarah di Awal 2020" https://www.beritasatu.com/jajasuteja/hiburan/594791/film-nkcthitorehkan-sejarah-di-awal-2020 diakses pada 22 Agustus 2020 jam 14:02.

[12] bookmyshow.com. "10 Film Indonesia Terlaris Kuartal Pertama Tahun 2020" https://id.bookmyshow.com/bloghiburan/10-film-indonesia-terlariskuartal-pertama-tahun-2020/ diakses pada 22 Agustus 2020 jam 16:02.

[13] Lahyanto Nadie. 2019. Media Massa dan Pasar Modal: Strategi Komunikasi Bagi Perusahaan GoPublic. Jakarta: Pustaka Kaji. Hal. 8.

[14] Firsan Nova. 2009. Crisis Public Relation: Bagaimana $P R$ Menangani Krisis Perusahaan. Jakarta: Grasindo. Hal. 204.

[15] Tommy Suprapto. 2009. Pengantar Teori \& Manajemen Komunikasi. Yogyakarta : MedPress. Hal.19,

[16] Khomsahrial Romli. Loc.cit.

[17] Tommy Suprapto. Loc.cit.

[18] Firsan Nova. Loc.cit.

[19] Nurudin. 2011. Pengantar Komunikasi Massa. Jakarta: PT. Rajagrafindo Persada. Hal. 3-4.
[20] Anton Mabruri KN. 2013. Manajemen Produksi Program Acara TV. Jakarta: Gramedia Widiasarana. Hal. 2-3

[21] ibid.

[22] Stanley J. Baran. Op.cit. Hal. 235

[23] Onong Uchjana Effendy. 2007. Kamus Komunikasi. Bandung: CV Mandar Maju. Hal. 210

[24] ibid.

[25] Nurbayati, Husnan Nurjuman, Sri Mustika. 2017 "Konstruksi Media Tentang Aspek Kemanusiaan Pada Poligami (Analisi Isi Terhadap Film Surga Yang Tak DiRindukan)". Jurnal Riset Komunikasi Vol 8, No 2 (2017). Program Studi Ilmu Komunikasi FISIP Universitas Sultan Ageng Tirtayasa. Hal 103-124

[26] ibid.

[27] Peter L. Berger and Thomas Luckmann. 1966. The Social Construction of Reality A Treatise in the Sociology of Knowledge. New York: Penguin Books.

[28] Burhan Bungin. (2008). Konstruksi Sosial Media Massa. Kekuatan Pengaruh Media Massa, Iklan Televisi \& Keputusan Konsumen Serta Kritik Terhadap Peter, L. Berger \& Thomas Luckmann. Jakarta: Kencana Prenada Media. Hal. 214

[29] History.2009. First commercial movie screene. https://www.history.com/thisday-in-history/first- diakses pada 22 Agustus 2020 jam 14:33.

[30] Onong Uchjana Effendy. Op.cit. Hal. 226

[31] Pratista Hilmawan. 2008. Memahami Film. Yogyakarta: Homerian Pustaka. Hal. 24

[32] Anton Mabruri KN. Loc.cit.

[33] Stanley J. Baran. Op.cit. Hal. 231.

[34] okezone.com. "Ini 5 Film Propaganda Terpopuler" https://nasional.okezone.com/read/2017/ 09/19/337/1779137/ini-5-filmpropaganda-terpopuler diakses pada 23 Agustus 2020 jam 13:45.

[35] boombastis.com. "Jenius! Ini 5 Propaganda Terselubung di Balik Film Heroik Amerika" https://www.boombastis.com/propagand a-film-amerika/65061 diakses pada 22 Agustus 2020 jam 13:41. 
[36] liputan6.com. "10 Kartun Disney Ini Ternyata PropagandaPerang?" https://www.liputan6.com/global/read/28 48040/10-kartun-disney-ini-ternyatapropaganda-perang diakses pada 22 Agustus 2020 jam 13:43.

[37] Jallaludin Rakhmat. 2011. Psikologi Komunikasi. Bandung: PT Remaja Rosdakarya. Hal. 217.

[38] K. Krippendorff. 2004. Content analysis: an introduction to its methodology (2nd ed.). London: Sage Publications.

[39] Bonaventura Satya Bharata. 2011. "Analisis Isi Kuantitatif, Sebuah Pengantar Untuk Penelitian Teks Komunikasi" dalam Mix Methodologi
Dalam Penelitian Komunikasi. Aswad Ishak, et. al. (ed.). Badan Litbang ASPIKOM. Yogyakarta: Buku Litera. Hal.97.

[40] H.F. Hsieh and Shannon, S.E. 2005. Three Approaches to Qualitative Content Analysis. Thousand Oaks, California: Sage Publication.

[41] imdb.com "Nanti Kita Cerita Tentang Hari Ini (2020) "https://www.imdb.com/title/tt107 73114/?ref =ttpl ql diakses pada 23 Agustus 2020 jam 14:35.

[42] tirto.id. "Sinopsis Film NKCTHI yang Kembali Tayang di Netflix 23 Mei 2020", https://tirto.id/fq2Y diakses pada 24 Agustus $2020 \quad$ jam $13: 2$ 